\title{
HUBUNGAN POLA KONSUMSI PANGAN KELUARGA DI DAERAH PENGHASIL TEMBAKAU TERHADAP KEJADIAN GAKI PADA ANAK SD
}

\author{
Kartika Pibriyanti' ${ }^{1}$, Oktia Woro $\mathrm{KH}^{2}$, Intan Zainafree ${ }^{2}$ \\ Fakultas Kesehatan Masyarakat, Universitas Veteran Bangun Nusantara Sukoharjo ${ }^{1}$ \\ Jurusan Ilmu Kesehatan Masyarakat Fakultas Ilmu Keolahragaan \\ Universitas Negeri Semarang \\ Gedung F1, Lantai 2, Kampus Sekaran, Gunungpati, Semarang²
}

\begin{abstract}
Iodium Deficiency Disorder (IDD) is a group of syndrome which emerges because the human body is continously lack of iodine for a long time. Mudal village has been an endemic region since 2008. In 2012, it was still endemic region with 35,34\% of TGR. The purpose of this study was to analyze the food consumption, including iodine, goitrogen, protein consumption and salt quality. This was an explanatory research with crosssectional approach. The number of population was 153 students. The number of sampel was 58 students. The instruments used were semi-quantitatiffood frequency questionnaire, iodine test and test of iodine excretion in urin. Data analysis was done using univariate and bivariate (Chi Square). The result of this study showed that there were relationships between consuming food which rich iodium food ( $p=0,003)$, consuming food which contains goitrogen ( $p=0,004, O R=0,097, C I=0,020-0,483)$, consuming protein $(p=0,002$, $O R=18,158, C I=2,194-150,291)$ and salt quality $(p=0,030, O R=5,246$, $C I=1,300-21,160)$ towards iodium deficiency disorders (IDD).
\end{abstract}

Keyword: Iodine Deficiency Disorder (IDD), family's food, comsumption pattern, Temanggung

\begin{abstract}
Abstrak. GAKI merupakan sekumpulan gejala yang timbul karena tubuh seseorang kekurangan unsur iodium secara terus menerus dalam jangka waktu cukup lama. Desa Mudal merupakan daerah endemis sejak tahun 2008. Pada tahun 2012, daerah ini masih tergolong endemis dengan TGR 35,34\%. Tujuan penelitian adalah menganalisis pola konsumsi makanan tinggi iodium, makanan mengandung goitrogen, konsumsi protein dan kualitas garam. Jenis penelitian ini Explanatory Research dengan pendekatan Cross Sectional. Populasi berjumlah 153 anak. Sampel berjumlah 58 anak. Instrumen yang digunakan adalah kuesioner frekuensi pangan semikuantitatif, iodina test dan uji kandungan iodium dalam urin. Analisis data dilakukan secara univariat dan bivariat (chi square). Hasil penelitian dan simpulan menunjukkan ada hubungan antara konsumsi makanan tinggi iodium $(\mathrm{p}=0,003)$, konsumsi makanan mengandung goitrogen $(p=0,004)$, konsumsi protein $(p=0,002)$, kualitas garam $(p=0,030)$ terhadap kejadian GAKI.
\end{abstract}

Kata Kunci: GAKI; pangan keluarga, pola konsumsi, Temanggung 


\section{PENDAHULUAN}

GAKI merupakan sekumpulan gejala yang timbul karena tubuh seseorang kekurangan unsur iodium secara terus menerus dalam jangka waktu cukup lama (Suharyono Hadisaputro, 2008). Lebih spesifik Zimmerman (2009) menyebutkan dari hasil pemeriksaan ekskresi iodium dalam urin(UIE), sebanyak 2 milyar individu di dunia menderita defisiensi iodium dan 285 juta diantaranya adalah anak sekolah. Usia sekolah merupakan masa rawan terjadinya risiko kurang gizi termasuk defisiensi iodium (Mutalazimah, dkk, 2009). Anak Sekolah Dasar merupakan salah satu target yang direkomendasikan oleh WHO dalam melakukan survey GAKI (Dhuta Widagdo, 2009). Usia tersebut merupakan fase pertumbuhan fisik, fase proses pematangan organ reproduksi dan merupakan fase sensitif terhadap kekurangan unsur iodium (Triyono dan Inong Retno, 2004).

Penyebab langsung dari gangguan akibat kekurangan iodium adalah ketidakcukupan asupan iodium yang disebabkan oleh kandungan iodium dalam bahan makanan dan air rendah atau konsumsi garam beriodium yang rendah (Siti Arifah P, 2008). Menurut Mohammad Sulchan (2007), 4\% dari 200 juta orang di dunia yang sebagian besar tinggal di Indonesia mengalami kekurangan iodium yang disebabkan oleh konsumsi makanan goitrogen.

Menurut Dinkes Provinsi Jawa Tengah (2010), Temanggung merupakan daerah endemis GAKI. Besaran masalah GAKI di Kabupaten Temanggung direpresentasikan dari angka prevalensi TGR (Total Goiter Rate) pada anak Sekolah Dasar. Desa Mudal merupakan daerah endemis berat dengan TGR (Total Goiter Rate) sebesar 35,34\% (Dinkes Temanggung, 2011).

Kabupaten Temanggung terkenal sebagai produsen tembakau dengan kualitas terbaik dan merupakan sentra perdagangan tembakau di Jawa Tengah. Menurut Bupati Temanggung, uang yang beredar dari hasil tembakau sekitar Rp. 588.000.000.000,00 per tahun. Sekilas kondisi ini menunjukkan bahwa tingkat kesejahteraan para petani tembakau di
Kabupaten Temanggung cukup tinggi (Sulhi, 2010).

Berdasarkan studi pendahuluan yang telah penulis lakukan, jarak tempuh desa Mudal dengan ibukota kecamatan $3 \mathrm{~km}$ sehingga tidak memerlukan waktu yang terlalu lama jika hendak belanja ke pasar kabupaten untuk mendapatkan bahan makanan yang bervariasi.

Pada tahun 2011, luas tanaman tembakau di Desa Mudal 37 ha dengan nilai produksi Rp. 1.554.000.000,00 per tahun. Sekilas kondisi ini menggambarkan pendapatan yang cukup untuk memenuhi kebutuhan pangan sesuai menu ideal yang terdiri dari makanan pokok, lauk hewani, lauk nabati, sayuran dan buah. Perencanaan penyediaan makan keluarga sering tidak diperhatikan. Hal tersebut tergambar dalam penyediaan menu seharihari dengan memanfaatkan sayuran golongan goitrogen yang ditanam disekitar rumah dan kurang bervariasi.

Penelitian ini bertujuan untuk meneliti hubungan pola konsumsi pangan keluarga di daerah penghasil tembakau terhadap kejadian GAKI pada anak SD (Studi Kasus di Desa Mudal Kabupaten Temanggung).

\section{METODE PENELITIAN}

Jenis penelitian yang digunakan adalah Explanatory Research dengan rancangan cross sectional. Penelitian dilakukan di SDN 1 dan SDN 2 Mudal. Subjek dalam penelitian ini adalah anak SD kelas 4,5 dan 6 dan Ibu anak SD sebagai responden. Untuk menentukan sampel dengan proportional stratified random sampling. Sampel dalam penelitian ini sebanyak 58 sampel. Variabel bebasnya adalah makanan tinggi iodium, makanan mengadung goitrogen, konsumsi protein dan kualitas garam, sedang variabel terikatnya adalah kejadian GAKI. Instrumen yang digunakan adalah kuesioner frekuensi pangan semikuantitatif, iodina test dan uji kandungan iodium dalam urin. Analisis data dilakukan secara deskriptif untuk menggambarkan keadaan subjek dan responden. Analisis analitik untuk menguji hipotesis dengan teknik statistik chi square dengan uji alternatif Fisher. 


\section{HASIL DAN PEMBAHASAN}

Tabel 1. Distribusi pola konsumsi pangan

\begin{tabular}{llccc}
\hline & \multicolumn{1}{c}{ Sumber pangan } & \multicolumn{2}{c}{ Jumlah } \\
\cline { 3 - 4 } Iodium & Tinggi & n & \% \\
\cline { 2 - 4 } Goitrogen & Rendah & Tinggi & 16 & 72,4 \\
& Rendah & 42 & 27,6 \\
\multirow{2}{*}{ Protein } & Baik & 31 & 53,4 \\
& Sedang & 27 & 46,6 \\
& Kurang & 12 & 20,7 \\
\multirow{2}{*}{ Kualitas } & Defisit & Tidak beriodium (tidak berwarna ungu) & 12 & 20,7 \\
& Kurang beriodium (berwarna ungu muda) & 15 & 25,9 \\
& Beriodium (berwarna ungu tua) & 19 & 32,7 \\
& & & 4 & 6,9 \\
& & & 28 & 48,3 \\
& & & 26 & 44,8 \\
\hline
\end{tabular}

Menyimak tabel 1, hasil penelitian ini menemukan jumlah konsumsi makanan tinggi iodium dengan asupan iodium tinggi yaitu 16 subjek $(72,4 \%)$ dan rendah yaitu 42 subjek (27,6\%), konsumsi goitrogen tinggi 31

subjek (53,4\%) dan rendah 27 subjek (46,6\%), konsumsi protein baik yaitu 12 subjek $(20,7 \%)$, sedang 12 subjek (20,7\%), kurang 15 subjek $(25,9 \%)$ dan defisit 19 subjek $(32,7 \%)$.

Tabel 2. Hubungan Pola Konsumsi Pangan terhadap Kejadian GAKI

\begin{tabular}{|c|c|c|c|c|c|c|c|}
\hline \multirow{3}{*}{ Konsumsi } & \multicolumn{4}{|c|}{ Kejadian GAKI } & \multirow{2}{*}{\multicolumn{2}{|c|}{ Jumlah }} & \multirow{3}{*}{$p$ value } \\
\hline & \multicolumn{2}{|c|}{ GAKI } & \multicolumn{2}{|c|}{ Tidak GAKI } & & & \\
\hline & $\mathbf{n}$ & $\%$ & $\mathbf{n}$ & $\%$ & $\mathbf{n}$ & $\%$ & \\
\hline \multicolumn{8}{|l|}{ Iodium } \\
\hline Tinggi & 0 & 0 & 16 & 27,6 & 16 & 27,6 & \multirow{2}{*}{0,003} \\
\hline Rendah & 16 & 27,6 & 26 & 44,8 & 42 & 72,4 & \\
\hline \multicolumn{8}{|l|}{ Goitrogen } \\
\hline Tinggi & 14 & 24,1 & 17 & 29,3 & 31 & 53,4 & \multirow{2}{*}{0,004} \\
\hline Rendah & 2 & 3,4 & 25 & 43,1 & 27 & 46,6 & \\
\hline \multicolumn{8}{|l|}{ Protein } \\
\hline Defisit + kurang & 15 & 25,9 & 19 & 32,8 & 34 & 58,6 & \multirow{2}{*}{0,002} \\
\hline Sedang + baik & 1 & 1,7 & 23 & 39,7 & 24 & 41,4 & \\
\hline \multicolumn{8}{|l|}{ Kualitas Garam } \\
\hline $\begin{array}{l}\text { Tidak beriodium }+ \text { beriodium } \\
\text { tidak memenuhi syarat }\end{array}$ & 13 & 22,4 & 19 & 32,8 & 32 & 55,2 & \multirow[t]{2}{*}{0,308} \\
\hline Beriodium sesuai syarat & 3 & 5,2 & 23 & 39,7 & 26 & 44,8 & \\
\hline
\end{tabular}

Berdasarkan Tabel 2, proporsi dari 16 sedangkan proporsi dari 42 subjek dengan subjek dengan konsumsi iodium tinggi 0 konsumsi makanan dengan kandungan iodium subjek GAKI dan 16 Subjek tidak GAKI, rendah 16 subjek GAKI dan 26 subjek tidak 
GAKI. Proporsi 31 subjek dengan konsumsi goitrogen tinggi terdapat 14 subjek GAKI dan 17 subjek tidak GAKI, sedangkan proporsi dari 27 subjek dengan konsumsi kandungan goitrogen rendah 2 subjek GAKI dan 25 subjek tidak GAKI. Proporsi dari 34 subjek dengan konsumsi protein defisit dan kurang 15 subjek mengalami GAKI dan 19 subjek tidak GAKI, sedangkan proporsi 24 subjek dengan konsumsi protein sedang dan baik terdapat 1 subjek GAKI dan 24 subjek tidak GAKI. Proporsi dari 32 subjek dengan kualitas garam tidak beriodium dan tidak memenuhi syarat terdapat 13 subjek GAKI dan 19 subjek tidak GAKI, sedangkan proporsi dari 26 subjek yang menggunakan kualitas garam beriodium sesuai syarat terdapat 3 subjek GAKI dan 23 subjek tidak GAKI.

\section{Hubungan konsumsi makanan tinggi iodium terhadap kejadian GAKI}

Hasil analisis hubungan konsumsi makanan tinggi iodium terhadap kejadian GAKI menunjukkan hubungan bermakna berdasar analisis uji Fisher ( $p$ value 0,003). Hasil penelitian menunjukkan bahwa rendahnya konsumsi makanan tinggi iodium menyebabkan subjek menderita GAKI. Letak Desa Mudal Kabupaten Temanggung merupakan daerah yang jauh dari laut sehingga meyebabkan penduduk sulit mendapatkan bahan makanan hasil laut. Menurut beberapa responden, ditempat mereka membeli bahan makanan sehari-hari yang jaraknya dekat rumah tidak selalu tersedia ikan laut. Ikan laut diperoleh dari pasar Kabupaten Temanggung dengan kategori kadang-kadang dikonsumsi (kurang dari tiga kali perminggu). Di Desa Mudal terdapat dua peternakan ikan tawar yang cukup besar sehingga membuat masyarakat lebih biasa mengkonsumsi (tiga kali perminggu) ikan tawar dibandingkan harus membeli ikan laut di pasar Kabupaten Temanggung.

Sumber makanan tinggi iodium umumnya berasal dari ikan laut dan sejenisnya. Sulitnya memperoleh bahan makanan dari laut, dapat disiasati dengan mengoptimalkan konsumsi makanan tinggi iodium lain seperti ikan tawar yang bersumber dari kolam ikan yang dikelola oleh keluarga, juga telur ayam yang diolah menggunakan garam beriodium.

Iodium merupakan mikronutrien esensial yang dibutuhkan oleh tubuh manusia. Iodium penting untuk reproduksi hormon tiroid yaitu hormon yang dibutuhkan untuk perkembangan dan pertumbuhan saraf otot pusat, pertumbuhan tulang, perkembangan fungsi otak dan sebagian besar metabolisme sel tubuh. Apabila jumlah iodium yang tersedia tidak mencukupi maka produksi hormone tiroksin dan triodotironin menurun dan sekresi Thyroid stimulating hormone (TSH) oleh pituitary meningkat, akibatnya sekresi triglobulin oleh sel tiroid meningkat, sebagai kompensasi kelenjar membesar dan terjadi hyperplasia (Djokomoeljanto,2007;Guyton,2008).

\section{Hubungan konsumsi makanan mengandung goitrogen terhadap kejadian GAKI}

Hasil analisis hubungan konsumsi makanan mengandung goitrogen terhadap kejadian GAKI menunjukkan hubungan bermakna berdasar analisis uji Fisher ( $p$ value 0,004. Nilai OR diketahui 0,097 yang berarti hal ini dapat diartikan konsumsi makanan dengan kandungan goitrogen yang tinggi berisiko 0,097 kali lebih besar mengalami kejadian GAKI dibandingkan subjek yang konsumsi goitrogennya rendah.

Goitrogen adalah zat yang dapat menghambat pengambilan iodium oleh kelenjar gondok, sehingga konsentrasi iodium dalam kelenjar menjadi rendah. Selain itu goitrogen dapat menghambat perubahan iodium dari bentuk anorganik kebentuk organik sehingga pembentukan hormon tiroksin terhambat (Djokomoeljanto,2007).

Bahan makanan yang mengandung zat goitrogen merupakan bahan makanan (sayur-sayuran) yang banyak tumbuh dan dibudidayakan di Desa Mudal, sehingga secara umum menjadi sayuran utama yang dikonsumsi sehari-hari oleh masyarakat. Bahan makanan golongan goitrogen yang 
dibudidayakan dipekarangan rumah oleh masyarakat Desa Mudal diantaranya adalah sawi, kangkung, bayam, ubi dan singkong. Kandungan goitrogen dalam daun singkong dan singkong dapat dikurangi sampai $10 \%$ dengan cara direbus) dan efek goitrogen dapat hilang bila dikonsumsi bersama dengan makanan yang mengandung iodium (Martha,2006; Ance,2001). Menurut beberapa responden, sawi merupakan sayuran yang paling digemari oleh subjek dengan kategori sering dikonsumsi (4-6 kali seminggu). Tentu hal tersebut tidak menguntungkan bagi golongan rawan gizi jika tidak diimbangi dengan konsumsi aneka ragam makanan terutama dengan kandungan iodium tinggi.

\section{Hubungan konsumsi protein terhadap kejadian GAKI}

Hasil analisis hubungan konsumsi protein terhadap kejadian GAKI menunjukkan hubungan bermakna berdasar analisis uji Fisher ( $p$ value 0,002). Nilai OR diketahui 18,158 , hal ini menunjukkan bahwa konsumsi protein yang tidak memenuhi angka kecukupan (defisit dan kurang) berisiko 18,158 kali lebih besar terhadap kejadian GAKI.

Protein berfungsi sebagai Thyroid Binding Protein (TBP), asupan protein mempengaruhi kadar protein dalam serum. Pengeluaran hormon tiroid dari kelenjar tiroid karena pengaruh Thyroid Stimulating Hormon (TSH) melalui membran basalis, penetrasi sel kapiler kemudian ditangkap oleh thyroid binding protein (TBP). Pada keadaan protein yang menurun menyebabkan kadar hormon total juga menurun, penurunan hormon dari kelenjar tiroid (terutama $\mathrm{T}_{4}$ ) akan menyebabkan hambatan umpan balik pada kelenjar hipofise dalam memproduksi Thyroid Stimulating Hormon (TSH) sehingga memacu kelenjar tiroid untuk meningkatkan fungsinya dalam upaya mencukupi kebutuhan hormon dari kelenjar tiroid (Normawaty Patuti, dkk, 2007).

Rata-rata asupan protein subjek masih dibawah angka kecukupan gizi apabila dibandingkan dengan angka kecukupan gizi
(AKG) yang dianjurkan tahun 2004. Hal ini disebabkan kebiasaan makan dengan porsi nasi lebih banyak dan lauk sumber protein dengan porsi sangat kecil. Lauk sumber protein cenderung hanya digunakan sebagai formalitas penghantar makan nasi. Subjek cenderung sering (lebih dari satu kali sehari) mengkonsumsi makanan sumber protein nabati (tahu dan tempe) daripada protein hewani.

Sumber protein hewani yang biasa dikonsumsi (tiga kali perminggu) pada umumnya adalah ayam, telur ayam, susu dan sosis. Diketahui 5,17\% dari 58 subjek pantang makan makanan sumber protein tertentu seperti udang. Dari hasil perkebunan tembakau, diharapkan berpengaruh terhadap perekonomian keluarga terutama pendapatan sehingga masyarakat mampu menyediakan pola makan yang sesuai dengan 13 Pesan Pedoman Umum Gizi Seimbang. Makanan sumber protein hewani yang berasal dari laut biasanya harga cenderung lebih mahal akan tetapi secara berkala masyarakat tetap harus memenuhi kebutuhan gizi terutama yang bersumber dari protein hewani tersebut.

\section{Hubungan kualitas garam terhadap kejadian GAKI}

Hasil analisis hubungan kualitas garam terhadap kejadian GAKI menunjukkan hubungan bermakna berdasar analisis uji Fisher ( $p$ value 0,030). Nilai OR 5,246, hal ini menunjukkan bahwa subjek yang mengkonsumsi garam dengan kualitas garam yang tidak beriodium dan beriodium tetapi tidak memenuhi syarat berisiko 5,246 kali lebih besar terhadap kejadian GAKI dibandingkan subjek yang memiliki kualitas garam beriodium sesuai syarat.

Garam merupakan salah satu bahan makanan yang diharapkan dapat memberikan kontribusi terhadap keberhasilan penanggulangan GAKI, oleh karena itu garam yang dikonsumsi masyarakat harus mengandung cukup iodium.

Pelaksanaan pengujian kandungan iodium dalam penelitian ini dilakukan 
dengan alat uji standar yang telah digunakan oleh instansi seperti Dinas Kesehatan dan Departemen Perindustrian dan Perdagangan. Dari hasil penelitian diketahui bahwa tidak semua garam mengandung iodium memenuhi syarat. Sebagian besar responden memilih garam berbentuk bata dengan kandungan iodium yang tidak memenuhi syarat karena kemasannya lebih besar daripada garam halus. Minat masyarakat yang rendah akan garam beriodium diungkapkan karena alasan garam beriodium yang berbentuk halus dianggap mempunyai rasa yang lebih pahit sehingga mereka lebih memilih menggunakan garam bata. Hal lain yang mempengaruhi penggunaan garam beriodium oleh rumah tangga adalah kurangya kesadaran produsen untuk memproduksi garam beriodium dengan memproduksi garam beriodium yang tidak memenuhi syarat. Kandungan iodium pada beberapa merek garam tidak sesuai dengan yang tertulis pada kemasan.

\section{SIMPULAN}

Ada hubungan bermakna antara konsumsi makanan tinggi iodium, konsumsi makanan mengandung goitrogen, konsumsi protein dan kualitas garam terhadap kejadian GAKI pada anak SD di Desa Mudal Kabupaten Temanggung.

\section{SARAN}

Saran yang dapat diberikan :

1. Bagi sekolah diharapkan dalam pelajaran sekolah disisipkan materi mengenai penyakit GAKI dan cara penanggulangannya untuk menambah pengetahuan siswa mengingat Desa Mudal merupakan daerah endemis.

2. Bagi masyarakat khususnya ibu rumah tangga disarankan untuk lebih memperhatikan penyediaan makan keluarga dengan menambah frekuensi maupun variasi makanan khususnya makanan tinggi iodium dan makanan sumber protein, mengurangi frekuensi penyediaan makanan mengandung goitrogen dan menggunakan garam beryodium sesuai persyaratan yaitu 30 80 ppm.

3. Bagi Puskesmas lebih ditingkatkan pelaksanaan upaya promosi kesehatan khususnya kesehatan keluarga melalui pemberdayaan masyarakat dan kader mengenai pola konsumsi pangan keluarga khususnya dengan mengoptimalkan konsumsi makanan tinggi iodium dan sumber protein, serta mengurangi konsumsi makanan mengandung goitrogen sebagai upaya program penanggulangan GAKI pada anak usia sekolah.

\section{DAFTAR PUSTAKA}

Ance Mardiana. dkk. 2001. Kadar Sianida dalam Sayuran dan Umbi-umbian di Daerah Gangguan Akibat Kekurangan Iodium (GAKI). Penelitian Gizi dan Makanan. DepKes RI

Departemen Kesehatan RI, 2010, Profil Kesehatan Provinsi Jawa Tengah, Semarang: Dinkes Provinsi Jateng

Departemen Kesehatan RI. 2011. Pofil Kesehatan Kabupaten Temanggung. Temanggung: Dinkes Kabupaten Temanggung

Djokomoeljanto, 2007, Fisiologi kelenjar tiroid (sintesis, sekresi, metabolisme dan efek hormon tiroid serta faal tiroid pada berbagai kondisi). Buku ajar tiroidologi klinik. Semarang BP UNDIP

Dhuto Widagdo, dkk, 2009, Faktor yang berhubungan dengan ekskresi yodium dalam urin di kabupaten Grobogan Jawa Tengah, Media penelitian dan pengembangan kesehatan volume XIX, Hal, S1-S94, Jakarta Desember 2009

Guyton, Hall, 2008, Buku ajar fisiologi kedokteran. Jakarta: EGC 
Martha Irene Kartasurya. 2006. Goitrogenik Subsances. Jurnal GAKI Indonesia. Vol.5. No. 1-2. April dan Agustus 2006

Mutazalimah dan Setya Asyanti. 2009. Status Iodium dan fungsi kognitif anak Sekolah Dasar di SDN Kiyaran 1 Kecamatan Cangkringan. Jurnal penelitian sains dan teknologi. Vol. 10. No. 1. 2009:50-60.

Mohammad Sulchan. 2007. Goiter in the Coaster Areas. Jurnal GAKI Indonesia Vol.5. No.3. Desember 2006 dan Vol.6. No.1. April 207.

Normawati Patuti. dkk. 2007. Faktor-Faktor yang Berhubungan dengan Kejadian GAKI pada Anak Sekolah Dasar di Pinggiran Kota Palu Provinsi Sulawesi Tengah. Jurnal Gizi klinik Indonesia Vol. 7 No. 1. Juli 2010: 17-26.

Siti Arifah P. 2007. Gizi dan Kesehatan Masyarakat. Jakarta: Raja Grafindo Persada

Suharyono Hadisaputro. 2008. http://www.kr.co.id/web/detail.php?sid=175659\&actmenu=38 diakses 13 Oktober 2011

Sulhi, 2010, Dilema Tembakau Si Emas Hijau. Intisari. Mei 2010, Kompas Gramedia Jakarta, hal. 14-20.

Triyono dan Inong Retno. 2004. Identifikasi Faktor yang di duga berhubungan dengan kejadian Gondok pada Anak Sekolah dasar di Daerah Dataran Rendah. Jurnal GAKI Indonesia volume 3. No. 1-3. april 2004. hlm. 7

Wisnu Cahyadi, 2008, Penentuan Kadar spesi yodium dalam garam beryodium yang beredar di pasar dan bahan makanan selama pemasakan dengan metode kromatografi cair kinerja tinggi pasangan ion, Media Medika Indonesia Volume 43, Nomor 1, Tahun 2008

Zimmerman MB. Iodine Deficiency and Women's Health. International council for control of iodine deficiency disorders. IDD. 2009. 